\title{
Donor fatigue phenomenon: Trend and circumvention in Northern Ghana
}

\author{
Adam Cassia Awadari ${ }^{1}$ \\ Research Consultant, Author It GH ${ }^{1}$ \\ kingcacia@gmail.com
}

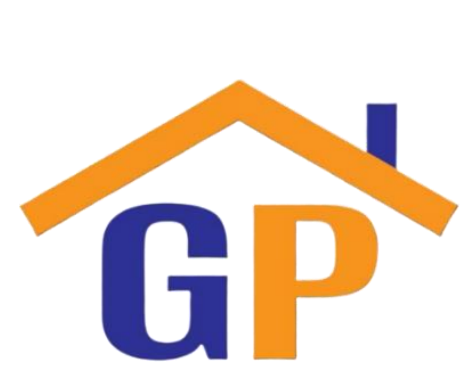

\begin{abstract}
Purpose: This study examines the phenomenon of donor fatigue and its implication on donor funding for local-NGOs. It further explores alternative ways of generating funds locally.

Research Methodology: Convenient sampling method was used for selecting the sample for the study. The design involves collecting data from five (5) selected international donors, thirty (30) partner organization staffs, twenty-two (22) direct beneficiaries and fifteen (15) team leaders/council members of the partner organizations.
\end{abstract}

Results: Donor funds have been on the decline due to donor

Article History

Received on 18 February 2020

$1^{\text {st }}$ Revision on 4 March 2020

$2^{\text {nd }}$ Revision on 24 March 2020

Accepted on 3 April 2020 fatigue, over dependency syndrome, poor proposal writing, improper management of donor funds, frequent changes in the interest areas of donors, changes in the policy direction of donor countries and the increasing number of local-NGOs competing for the same funds.

Limitation: The conclusion drawn may not be representative of all the NGOs in Ghana as they may not all have similar funding sources and challenges

Contribution: The finding will serve as a guide and logical framework for existing and potential local-NGOs on donor requirements for funding.

Keywords: Donor fatigue, Donors, Funding, Prospects, LocalNGOs, Dependency syndrome

How to cite: Awadari, A. C. (2020). Donor fatigue phenomenon: Trend and circumvention in Northern Ghana. International Journal of Financial, Accounting, and Management, 1(4), 191198.

\section{Introduction}

The three main actors in the development process of an economy are the government, the private sector and civil society (which include Non-governmental organizations). The government is the major stakeholder in the developmental needs of a country, especially in developing countries. Governments alone cannot, however, cope with all the developmental needs of its citizenry. Thus, most governments encourage the private sector and Non-governmental organization (NGOs) to complement their developmental efforts.

In general, NGOs play a crucial role in national development by fostering people's self-reliance, developing human resources and quality of life of people, thereby increasing local people's income and increasing productivity (Fowler, 1998). NGOs work to promote the economic and social development of the poorer nations of the world especially the underprivileged in society. Their traditional role had been in education and health by today, they have expanded to agriculture, fisheries production, rural water supply, environmental protection, poverty eradication, child rights and development, women empowerment, minority rights, gender right, and inequalities (Williams, 2016). Developing countries with a low gross domestic product and low per capita income are unable to 
support the funding of NGOs as compared to the developed countries. They, therefore, rely heavily on International Non-Governmental Organization (INGO) from the developed nations.

Recent empirical data have indicated a decline in donor funding and the folding up of most localNGOs and projects due to donor fatigue phenomenon. These trends are likely due to increased pressure on foreign aid budgets, changes in funding policy, over-reliance on single sources of funding, the increasing numbers of NGOs competing for funds for similar projects and overexposure on a particular issue (Green and Matthias, 1977).

The expenditure patterns of most NGOs are usually made up of the project and overhead costs. The project costs relate to those expenses which can be directly traced to a particular project. These are the costs that donors are usually interested in funding. The overhead costs, which constitute general administrative expenses, wages and salaries and other indirect costs are seldom funded by donors. External funders tend to favor project funding because they are well defined and can be isolated from other activities. This, however, militates against NGOs institutional capacity building since funds are only provided for project-related activities and not for general organizational overheads (Gibbs, et al. 2019). Generally, only those local NGOs who can satisfy the donors with their project reports and meet their evaluation criteria will get funds (Adams, 2002). One major challenge facing NGO funding is the fact that the donors' priorities may shift in an arbitrary manner unrelated to the needs and priorities of the countries or local NGOs. These conditions and many more, coupled with the lack of trust of some western donor agencies for their partners in the developing countries have led to funding challenges (Fowler, 1998).

The purpose of this paper, therefore, is to examine the phenomenon of donor fatigue and its implication on donor funding and local-NGOs sustainability. The specific objectives, seek to:

- Identify funding sources available to local-NGOs.

- Find out what conditions if any, are attached to each source of funds.

- Examine funding challenges facing local-NGOs.

- Discuss finding prospects and Make recommendations to improve funding.

To effectively find answers to the research objectives and offer the best way to obtain research solutions, it was also important to look at the following research questions:

1. What are the major sources of funds for local-NGOs?

2. What conditions are attached to these sources?

3. What funding challenges confront local-NGOs?

4. How can alternative sources of funding be identified?

\section{Literature review and hypotheses development}

\subsection{Funding challenges of NGOs}

A joint study by Charity Aid Foundation (CAF) and British Overseas NGOs for Development (BOND) has identified increased competition, changes in funding policy and over-reliance on single sources of funding as some of the major threats to NGOs sustainability. Also, the level of accountability demanded by funders is beyond their skills and resources. This makes it increasingly difficult for smaller NGOs to secure funding (Delisle, et al. 2005). In addition, the biggest challenge revealed was the belief that funders where dictating NGO agenda and targeting their funding lines with their own priorities. Donors' priorities may shift in an arbitrary manner unrelated to the needs and priorities of the countries or local NGOs. A case in point is the generous allocations for population programs, following the World Population Conference of 1974, which encourage NGOs to slant their projects in this direction to take advantage of the availability of funds. The current reduction and withdrawal of funds for these programs as well as their restricted use as a result of US government policies have had a negative impact on programs throughout the world. A related issue is an extent to which some donors claim the right to influence or direct the programs or projects that they fund. This is often difficult to discern, although there are times when the arrogance of a major 
donor overrides the boundaries of decency and applicants are reminded that "the one who pays the piper calls the tune".

\subsection{Conditions attached to funding sources}

Antrobus (1987), argues that donors perceive that NGOs in many instances can provide comparable services more cost-effectively than governments. This, they say, stems from their flexibility and aptitude for innovation. NGOs are also perceived to have the ability to "reach the grassroots" in ways the large government bureaucracies cannot. These perceptions or claims have led to an increased interest in funding NGOs for development programs. Donor agencies, however, have procedures and specific requirements that may be rigorous, frustrating or unacceptable to the local NGOs. Brown et al. (2001), identified the following general conditions or factors affecting the ability of local or indigenous NGOs to attract funds: NGOs track-record and credibility with the donor, their management systems and ability to absorb funds, the extent to which their priorities, activities, and methodologies are compatible with those of donors, the level of support they receive from their governments and their knowledge of and access to external funds.

\subsection{Funding Sources Available to NGO's}

NGOs mobilize resources in the form of donations in cash and kind, charges to direct users for services provided, tax relief subsides, charges for the provision of services to other organizations, lotteries, and other fund-raising mechanisms to sustain their projects and programs (Green and Matthias (1977). The donations in cash and kind may be in the form of charity shops staffed by volunteers or attracting nominal rents and selling donated goods to provide funding for national headquarters (Longton, 1981). Financial donation may occur through street collections, media appeals, and targeted soliciting of support which requires time and expertise spent on planning, preparing budgets, accounting, and reporting. Brealey et al. (2001), also adds that the second source of funding which is charged to direct users relates to the sale of services provided to individual users. A practical example is the provision of curative personal health care for a fee. Indeed, 8 out of 12 health NGOs studied in India revealed this as their main funding source. The third source of funding for NGOs comes from the provision of services like facilitation of training to, or on behalf of other organizations for which the latter pays. These organizations may include government ministries, other NGOs or the private sector (Antrobus, 1987). NGOs may also receive funding from various institutional sources (as grant and materials) including their country government, donor agencies and international NGOs which are not tied up to any particular program or project. This source has the benefit of flexibility for NGOs though donors require organizations to work in a way that is consistent with donor policies. According to the Global Policy Forum (2003), funding sources can seriously affect NGO policy and make these organizations potentially creatures of special interests. Such arguments challenge NGOs' legitimacy about rich foreign governments, corporations or foundations. Donations from governments or pro-government organizations both within and outside sometimes undermine the NGOs' independence.

\subsection{Funding Prospects of NGOs}

Palmer-Buckle (2005), posited that the prospects of local NGOs securing funds for their projects and programs can be looked at from two dimensions: those which simply aid NGOs to secure funds from donor agencies and those which help to build organizational self-reliance through the acquisition of their independent source. The first options were gained through personal experience with the women and Development Unit of the Extra-Mural Department of the University of West Indies. The strategies used by this unit to continue to secure funding from donors included paying attention to the pursuit of good record-keeping, financial accountability, good management practice, alongside its sustained record for innovative and effective programs and projects. To avoid dependency on a single donor or a few sources, the unit deliberately sought funds from several donor agencies (Guthrie et al., 2005; Lewis, 2003; Ayaga, 2000). Samuel \& Thanikachalam (2003), recommends that local-NGOs should inculcate innovative financing techniques that shift from reliance on a small group of international donors to a more diversified base of local support. This, therefore, is a wake-up call for local NGOs to explore local prospects of funding rather than rely on a few international donors. 


\section{Research methods}

The study is a case study type it is intended to study the funding sources, expenditure items, prospects and challenges of funding for local-NGOs. The research found it appropriate to use a case study method in other to allow an in-depth investigation of the change in the phenomenon of donors. This method would also allow for the collection of information regarding the source of funding, conditions attached to donor funding, level of expenditure on budget lines and the identification of the alternative source of funding. The design involves collecting data from five (5) selected donors (Christian Children Fund of Canada, CORDAID of the Netherlands, Catholic Relief Services USA, World Vision International, and CARE International), thirty (30) partner organization staffs, twenty-two (22) direct beneficiaries in the communities and fifteen (15) team leaders/council members of the partner organizations. The convenience sampling method was used to select members of staff who had access to funding information and had served the office for at least five years. This helped to assess funding patterns and challenges. The same method was applied in the selection of the Team leaders/Council members and representatives from the communities who are beneficiaries. The team leaders/council member were either sitting members or ex-member who have served for at least three years and the community representative were direct beneficiaries who have previously or currently on the Program for the past two years. This was to ensure that those selected had enough insights into its funding challenges and prospects. The questionnaire for the donors was focused on their policies for sending funds to developing nation's NGOs, the areas of development work they were interested in funding the conditions attached to their funds, challenges, and prospects of their sources of funds, and the plans for their development partners in the developing world. The staff had their questionnaire focusing on challenges and prospects of funding, while the questionnaire for the development council members centered on policy issues and implementations. The guided interview was used for the community member as most of them could not read and write. It centered on the role of the community in resource mobilization, project sustainability, and challenges.

\section{Results and discussions}

\subsection{The trend of donor funding}

The trend of donor funding was examined to find out its stability once it constituted the major source of funding so that precaution could be taken against any future adverse movement. An assessment of the consolidated accounts of the local-NGOs showed a declining trend. The reasons given by the selected staffs for the decreasing trend of donor funds were: donor fatigue, chunk of funding now going through government, church members in donor country who contribute to the donor pool now on decline, change in donor policies and interest areas, diversification of funds to include non-church NGOs, lack of trust in partners in the developing countries, poor accountability by partners, difficult economic conditions in donor countries and slow impact of donor funds in alleviating poverty. Comparing donor funds with internally generally funds (IGF), all respondents preferred IGF since it could be more sustainable and reliable. They, however, said that the IGF was insufficient to meet their budgets hence they would still rely on donor funds for major programs whilst intensifying on IGF to fund other activities. This confirms the findings by Samuel \& Thanikachalam (2003) that there was a wake-up call for IGF instead of relying on international donors.

\subsection{Potential sources of funds}

The following areas were identified by the respondents as possible sources of funds: local fundraising from the Ghana Poverty Reduction Strategy (GPRS) Project, income from training and research, District Assembly, donations from individuals and organizations, NGOs like Action Aid Ghana, World Vision International, PLAN Ghana, CARE International, Ghana AIDS Commission. The sources of donor funding were grants from government and donations from individuals, international donor community and organizations. The four selected donors indicated that their major source of funding was from their respective governments. For instance, $75 \%$ of CORDAID funding comes from the Netherlands government while 15\% comes from private persons and institutions with the remaining $10 \%$ from the international donor community. The donors indicated that their funds were usually channeled to their partners in Africa, South America, Asia, and the Middle East. Christian Children's Fund of Canada (CCFC) said their funding policy was to eradicate poverty by empowering 
the most vulnerable in society (women and children). CARE International, however, said $50 \%$ of their funds were reserved for Africa and the last donor CRS said they would fund projects in Africa that fall in line with their vision and mission.

\subsection{Conditions attached to sources of funds}

Donors normally attach certain conditions to the funding they provide to developing nations in the form of grants or loans. These conditions are put in place to regulate the use of the funds and also serve as a basis for future monitoring and evaluation. This is to ensure prudent and effective use of the funds. Some of these conditions, however, are normally at variance with the realities on the ground thus making program implementation difficult. The conditions identified by the staffs included: good proposal for funding, good implementation structural outline, and good reports (both narrative and financial). Team leaders/council members on their part indicated: transparency and accountability in project implementation, proposals must be seen to be addressing gender issues, the community must contribute locally towards maintaining and sustaining the projects, restructuring of systems in line with donor requirements, and the proposal should be in line with interest areas of donors. The donors, on their part, gave the following as their conditionality's: the proposals must contribute to the strategic plans of their respective organizations, proposals must be well designed starting with an analysis of problems or issues to be addressed, defining results to be achieved and matching project activities with budgets, projects should be seen to be contributing to addressing systematic and structural issues of poverty and deprivation, and objective must be SMART (i.e. specific, measurable, achievable, realistic and time-bound). These also include meeting reporting deadlines, contributing locally to the projects, equal employment opportunities, i.e. employing people from various social and religious backgrounds. Catholic Relief Services, on the other hand, mentioned that proposals should not conflict with teachings of the Catholic Church.

\subsection{Expenditure level and trend}

The major expenditure components of local-NGOs are divided into two: the program cost and the administrative overheads. Program costs are usually those associated with direct activities of the project being implemented. Administrative overheads are those expenses not directly linked to a particular project. The program cost normally constituted the major cost $(91 \%$ - 97\%) of the entire cost of the project. For example, vehicle purchase purposely for a particular project becomes program cost. The administrative cost, however, makes up a smaller percentage between $3 \%$ and $9 \%$. For instance, electricity and water bills, rents of buildings are termed administrative overheads. When donors were asked which expenditure lines they would normally not fund, three of the donors said the salary of non-project staff and one said administrative expenses. The study also confirms what Antrobus (1987) said that another challenge of NGO financing is the reluctance of many donors to fund salaries of NGO staff, particularly support staff. Thus, the various budgets of the local-NGOs were normally shaped according to donor taste "the one who pays the piper calls the tune".

\subsection{Funding challenges}

The funding challenges of local-NGOs were analyzed to find ways of minimizing these challenges if not completely eradicated. The challenges are presented according to the four categories of the respondents as shown in Table 1.

Table 1: Funding Challenges

\begin{tabular}{|l|l|}
\hline Respondent & Challenges \\
\hline Staff & Dwindling donor funding and change in interest areas of donors. \\
& Donor fatigue due to dependency syndrome. \\
& Improper management of funds leading to donor withdrawal. \\
& The proliferation of "non-man" NGO dubbed Non-Governmental \\
& Individuals (NGIs) which are better able to attract funding. \\
& Late implementation of project activities. \\
\hline Council & Donor fatigue due to over-reliance on donors. \\
members & Development projects not being sustainable to generate own income. \\
\hline
\end{tabular}

2020 | International Journal of Financial, Accounting, and Management/ Vol 1 No 4, 191-198 


\begin{tabular}{|l|l|l|} 
& $\begin{array}{l}\text { withdrawal of their funds after supporting them for some time. } \\
\text { Donors }\end{array}$ & The inability of partners in Africa to meet reporting requirements. \\
& Low-quality proposal presented to them for funding e.g. "shopping list", \\
& and not analytical and systematic. \\
& Some requests conflict with the national policy of donor countries. \\
& Some budgets do not have a direct bearing on the activities.
\end{tabular}

\section{6 funding prospects}

The following suggestions were given by respondents on how to minimize funding challenges. This also helped the researcher to derive the funding prospects. The suggestions are summarized under the various categories of the respondents as shown in Table 2.

Table 2: Suggestions for Addressing Funding Challenges by Respondents

\begin{tabular}{|c|c|}
\hline Respondent & Suggestions \\
\hline Staff & $\begin{array}{l}\text { Local-NGOs should familiarize themself with proposal formats and } \\
\text { requirements of donors. } \\
>\quad \text { Local-NGOs should co-operate and network with funding agencies and } \\
\text { other development partners. } \\
>\quad \text { Local-NGOs should concentrate on internally generated funds and other } \\
\text { local sources of income. } \\
>\quad \begin{array}{l}\text { Management should also institute sound financial management practices } \\
\text { to monitor funds. }\end{array} \\
>\quad \text { Local-NGOs should train all senior staffs on budgeting and budgetary } \\
\text { controls, as well as organizing fundraising activities. } \\
>\quad \text { Local-NGOs should set up common-funds for the various communities in } \\
\text { which it operates. } \\
>\quad \text { Grants to communities should be treated as loans with little interest to } \\
\text { make funds sustainable. } \\
>\text { Local-NGOs should establish commercial and business enterprises. }\end{array}$ \\
\hline $\begin{array}{l}\text { Council } \\
\text { members }\end{array}$ & $\begin{array}{l}\text { The Development council should set-up a charity board that will be } \\
\text { responsible for fundraising locally to supplement donor funds. } \\
\text { Local-NGOs should build the capacities of individuals to generate their } \\
\text { income. } \\
>\text { Constant monitoring of project } \\
\text { Local-NGOs should appoint competent personnel to man its various units. } \\
\text { Management should ensure adequate information is reported to donors. } \\
\text { Local-NGOs should encourage group savings as a means of obtaining } \\
\text { loans from the banks. }\end{array}$ \\
\hline Donors & $\begin{array}{l}\text { Joint partnership reflections and planning sessions between donors and } \\
\text { partners. } \\
>\text { Frequent and more open dialogue with partners. } \\
>\text { Capacity building of partner's staff on fundraising skills by the } \\
\text { development council. } \\
>\text { Local-NGOs should present quality proposals that are more focused on } \\
\text { specific issues. } \\
\text { Local-NGOs should be more proactive in their approach for support by } \\
\text { identifying the needs of the community and prioritizing them. } \\
>\text { The aid should commensurate the needs so identified. } \\
>\text { Community members should rely on income-generating activities so that }\end{array}$ \\
\hline
\end{tabular}


the government and NGOs could supplement their efforts.

Education, capacity building, and skill training should be embarked upon

by Local-NGOs and other stakeholders to reduce poverty and dependency

syndrome.

The suggestions can be grouped into two; suggestions that would aid Local-NGOs to secure funds from donors and those that would build Local-NGOs to become self-reliant as suggested by Antrobus (1987). The first group of suggestions deals with attention to be given to the pursuit of good record keeping, financial accountability, and good management practices. Local-NGOs should avoid dependency on a few donors by keeping watch on emerging donors and anticipating changes in donor interest areas. The second group of suggestions would aid the Local-NGOs secure funding from donors by presenting a good proposal that would focus on issues, registering Local-NGOs as a separate entity, and having a joint partnership between donors and local partners.

\section{Conclusion}

The findings of the study revealed that conditions were attached to donor funds. These were put in place to ensure the effective and prudent utilization of the funds. Some of the conditions identified by the study were: good proposals for funding, good logical frame for implementation, transparency and accountability in project implementation, proposals being in line with strategic plans of donor organization, meeting reporting guidelines, and encouraging locals to contribute towards project sustainability and management. The funding prospects for Local-NGOs were seen in their ability to mobilize local resources to become self-reliant, participation at the grass-root level to source funds locally and internally by opting to register as independent NGOs. Other areas of prospects include the engagement of the Local-NGOs in some commercial ventures like Agriculture, Microenterprise Development (MED), investment in treasury bills, diversifications into other areas of investment with accumulated funds from donors. Some past donors who withdraw for some reasons, dialogue and restructuring some systems could bring back some of these donors.

Based on the conclusions of the study, the following recommendations can be drawn: local-NGOs should build the capacity of their staff on fundraising skills, train staffs on quality proposal writing and appraisal to focus on specific issues and interests of donors. Donors and partners in developing countries should engage in more frequent and open dialogue on issues of mutual consent. Local NGOs should establish good financial management system for monitoring their resources and alternatively invest in both capital and money market with accumulated funds, establish consultancy units to raise funds, Local-NGOs should encourage group savings as a means of obtaining loans from the banks, grants to communities should be treated as loans with little interest to make funds sustainable and other commercial activities that are not ultra-virus.

\section{Acknowledgement}

I would like to express my profound thanks to local partner staffs, beneficiary communities and team leaders/council members of Christian Children Fund of Canada, CORDAID of the Netherlands, Catholic Relief Services USA, World Vision International, and CARE International in Northern Ghana for contributing in diverse ways towards this research. Finally, Many thanks to the editorial team of the International Journal of Financial, Accounting, and Management (IJFAM) for allowing me space and adding value to this article.

\section{References}

Adams, C.A. (2002). Internal organizational factors influencing corporate social and ethical reporting, Accounting, Auditing \& Accountability Journal, 15 (2), 223-50.

Antrobus, P. (1987). Funding for NGOs, issues and options, World Bank Development, 15, 95-105

Ayaga, M.A. (2000). Common values, contradictory strategies: case study of the church, state and $N G O$ relations in Ghana. Accra. Son life printing pres.

Brealey, R.A., Stewart, C. M., and Marcus, M, J. (2001). Fundamentals of corporate finance. Irwin. McGraw-Hill. 
Brown, L.D. and Moore, M. H. (2001). Accountability, strategy, and international Non-governmental organizations, Non-profit and Voluntary Sector Quarterly, 30 (3), 586-7.

Delisle, H., Roberts, J.H. \& Munro, M. (2005). The role of NGOs in global health research for development. Health Res Policy Sys, 3, 3. Doi.org/10.1186/1478-4505-3-3

Fowler, J. (1998). Non- governmental organizations in Africa, achieving a cooperative advantage in ' relief and micro development. Sussex. Institute of Development Studies publication.

Green, A. \& Mathias, A. (1977). NGOs and health in developing countries. London. Macmillan Press LTD.

Gibbs, C., Fumo, C. \& Kuby, T. (2019). NGOs in the world bank supported project. Washington DC. The World Bank.

Global Policy Forum (2003). Funding Non-governmental organizations. New York. Global policy newsletter.

Guthrie, J., Humphrey, C., Jones, L.R. and Olson, O. (2005). International public financial management reform: progress, contradictions, and challenges. Greenwich. Information age publishing.

Lewis, D. (2003). Theorizing the organization and management of non-governmental development organizations, Public Management Review, 5 (3), 325-344.

Longton, P.S. (1981). The new voluntarism, voluntary action research. Nairobi. University Press.

Palmer-Buckle, G. (2005). Building a self-reliant church: the role of a catholic student. Cape Coast. UCC local.

Samuel, R. \& Thanikachalam, V. (2003). Non-governmental organizations spearheading public participation in environmental issues. Toronto. York University.

Williams, E.O. (2016). Non-governmental organizations: their role in rural development in Kenya. Nairobi. A participatory action research publication. 